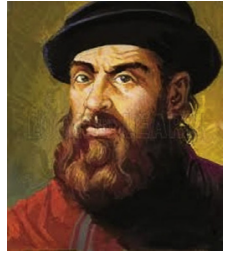

\section{THE EARTH IS ROUND!} To the Editor:

Ferdinand Magellan (1480-1521) (Figure 1) has been credited with being the first person in history to circumnavigate the Earth. Magellan was born into a noble Portuguese family and became a skilled sailor and naval officer. Following the eastern sea route to India that had been discovered by Vasco da Gama (1497-1498), Magellan participated in several Portuguese expeditions that reached as far as the Malaysian Archipelago in Southeast Asia between 1505 and 1512. This sea route brought immense wealth to the Portuguese Crown over the next century because they held a monopoly based on the Treaty of Tordesillas.

Fortunately, or unfortunately, Magellan fell out of favor with the Portuguese monarchy. Aware that Spain was desperately in need of a commercial route to Asia, in 1517 Magellan presented a proposal to the Spanish king, Charles I, to sail west in search of the spice route. Christopher Columbus had attempted this in voyages between 1492 and 1503, only to realize that the Americas were not a part of Asia, but rather a whole new continent. Subsequent voyages under the Spanish flag by Balboa reached the Pacific Ocean in 1513. Thus, the stage was set for Magellan, whose expedition left Spain in 1519. Magellan sailed southwest around the cape of South America and onward to the Marianas, Guam, and the Philippines. Magellan was killed during the Battle of Mactan in the Philippines (April 27, 1521), but because he had already visited this area in his previous trips from west to east, he achieved the complete personal circumnavigation of the globe. His expedition continued back to Spain, arriving on September 6, 1522, and thus providing tangible evidence that the world was round.

Ironically, the question of the shape of the Earth was still not resolved. It had been long held that the Earth was flat, and many sailors feared that if they sailed too far they would "sail off the edge of the Earth," a saying that remains with us to this day. This may have provided a convenient excuse for sailing expeditions that failed to identify a passage. However, nearly a century later, the

\footnotetext{
The Editor welcomes submissions for possible publication in the Letters to the Editor section that consist of commentary on an article published in the Journal or other relevant issues. Authors should: $\bullet$ Include no more than 500 words of text, three authors, and five references. • Type with double-spacing. • See http://jtcs.ctsnetjournals.org/ misc/ifora.shtml for detailed submission instructions. • Submit the letter electronically via jtcvs.editorialmanager.com. Letters commenting on an article published in the JTCVS will be considered if they are received within 6 weeks of the time the article was published. Authors of the article being commented on will be given an opportunity of offer a timely response ( 2 weeks) to the letter. Authors of letters will be notified that the letter has been received. Unpublished letters cannot be returned.
}

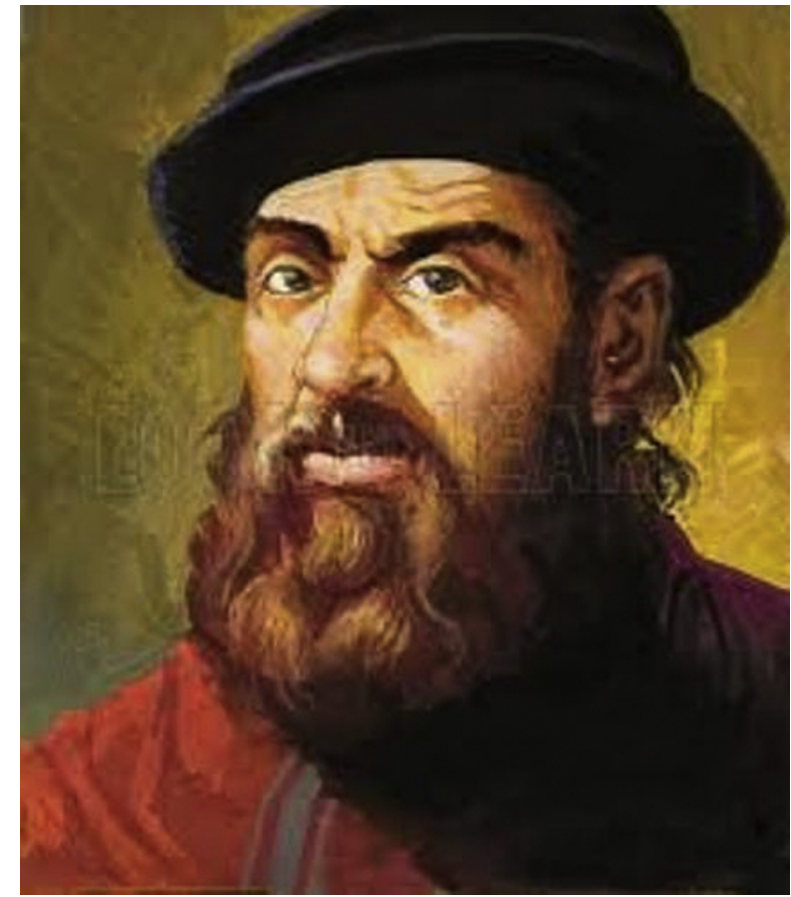

FIGURE 1. Ferdinand Magellan (1480-1521) was the first person to circumnavigate the globe. The Straits of Magellan along the tip of South America bear his name because he successfully navigated them to reach the Pacific Ocean.

Italian astronomer, physicist, and scientist Galileo Galilei (1564-1642) observed by telescope that the planets were round (Letters on Sunspots, 1612), a finding that was still considered new and controversial at the time despite the previous circumnavigation of our globe. Galileo also hypothesized that the Earth rotated around the sun (heliocentrism), a view that went beyond controversy but was considered blasphemy by the Roman Catholic Church, as it explicitly contradicted the Holy Scriptures. Galileo was tried by the Roman Inquisition in 1615, convicted of heresy, and was forced to recant his views and placed under house arrest for the remainder of his life. He may have gotten off lightly because other contemporaries were burned at the stake for espousing the same scientific views.

It seems to this author that the history of surgery for patients with pulmonary atresia/ventricular septal defect/ major pulmonary collateral arteries is recapitulating the history of the exploration of our planet. The first several decades of surgical strategies failed to achieve the desired goals of treatment, as aptly pointed by $\mathrm{Dr}$ Jane Sommerville. ${ }^{1}$ This would be analogous to the early explorations that sought but did not find the proper course around the capes. The natural conclusion was that the Earth was flat. However, in the mid-1990s, Dr Hanley pioneered the midline unifocalization technique, charting a course that successfully circumnavigated the globe and proving 
Authors have nothing to disclose with regard to commercial support.

that the Earth is round. ${ }^{2}$ There are many other groups, including those in Birmingham, Toronto, and Rome, who have followed that path and have independently confirmed that the Earth is round. It is not surprising that there are still skeptics of the midline unifocalization approach. As Dr Kumar has cited in his editorial, ${ }^{3}$ the skeptics have contended that "unifocalization confers no long-term benefit" 4 and have linked this outcome to their observation that major pulmonary collateral arteries are "abnormal vessels." ${ }^{5}$ However, if one goes back and looks at the underlying data to support these statements, it comes from an entirely different era and used the same antiquated strategy that was condemned by Dr Sommerville and subsequently abandoned. Thus, the skeptics are analogous to the sailors who did not find safe passage around the capes, turned back, and then have maintained that they did so because the Earth is flat and they did not want to sail off the edge.

For the young sailors who are interested in circumnavigating the globe, the question is: Who would you rather believe: those who have been around the world and contend that it is round or those who turned back and insist that the world is flat? Actually, history has answered this question. The Straights of Magellan bear his name because he successfully navigated through them and continued on his journey.

\section{Richard D. Mainwaring, MD \\ Frank L. Hanley, MD \\ Division of Pediatric Cardiac Surgery \\ Stanford University School of Medicine Lucile Packard \\ Children's Hospital \\ Stanford, Calif}

\section{References}

1. Bull K, Somerville J, Spiegelhalter D. Presentation and attrition in complex pulmonary atresia. J Am Coll Cardiol. 1995;25:491-9.

2. Mainwaring RD, Patrick WL, Roth S, Kamra K, Wise-Faberowski L, Palmon M, et al. Surgical algorithm and results for patients with pulmonary atresia with ventricular septal defect and major aortopulmonary collateral arteries. J Thorac Cardiovasc Surg. 2018;156:1194-204.

3. Kumar SR. Collateral benefit in pulmonary atresia with ventricular septal defect? J Thorac Cardiovasc Surg. 2018;156:1205-6.

4. d'Udekem Y, Alphonso N, Norgaard MA, Cochrane AD, Grigg LE, Wilkinson JL, et al. Pulmonary atresia with ventricular septal defect and major aortopulmonary collateral arteries; unifocalization brings no long-term benefits. J Thorac Cardiovasc Surg. 2005;130:1496-502.

5. Norgaard MA, Alphonso N, Cochrane AD, Menahem S, Brizard CP, d'Udekem Y. Major aorto-pulmonary collateral arteries of patients with pulmonary atresia and ventricular septal defect are dilated bronchial arteries. Eur J Cardiothorac Surg. 2006;29:653-8.

https://doi.org/10.1016/j.jtcvs.2018.10.047

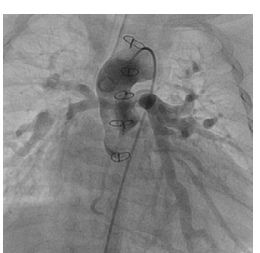

\section{SCIENTIFIC PROCESS}

Reply to the Editor:

I read with great interest the eloquent description by Mainwaring and Hanley of how Ferdinand Magellan successfully circumnavigated the earth, establishing that the earth is round. ${ }^{1}$ History is replete with examples of such pioneers who, against all odds, pursued what they believed in. Their resolve has moved the world forward in many ways. Such forward momentum has withstood many a criticism, theories of conspiracy, religious derision, and skepticism. Regardless, it is careful analysis of the approach, scientific scrutiny of the results, and unbiased evaluation of hypotheses that has convinced us beyond any doubt that the earth is round. And more importantly, such an approach has allowed us to find better ways to confirm that the earth is round, and more efficient modes to circumnavigate and enjoy the round earth.

The management of a complex and heterogeneous disease process such as pulmonary atresia with ventricular septal defect and major aortopulmonary collaterals would also benefit from such a rigorous scientific process. The work of pioneering health care providers, including the outstanding team at Stanford, has provided novel insights into managing this condition. More universal implementation of the lessons learned and reproducible outcomes (Figure 1) have vastly improved the prognosis of many a child who suffers from this disease process. However, there

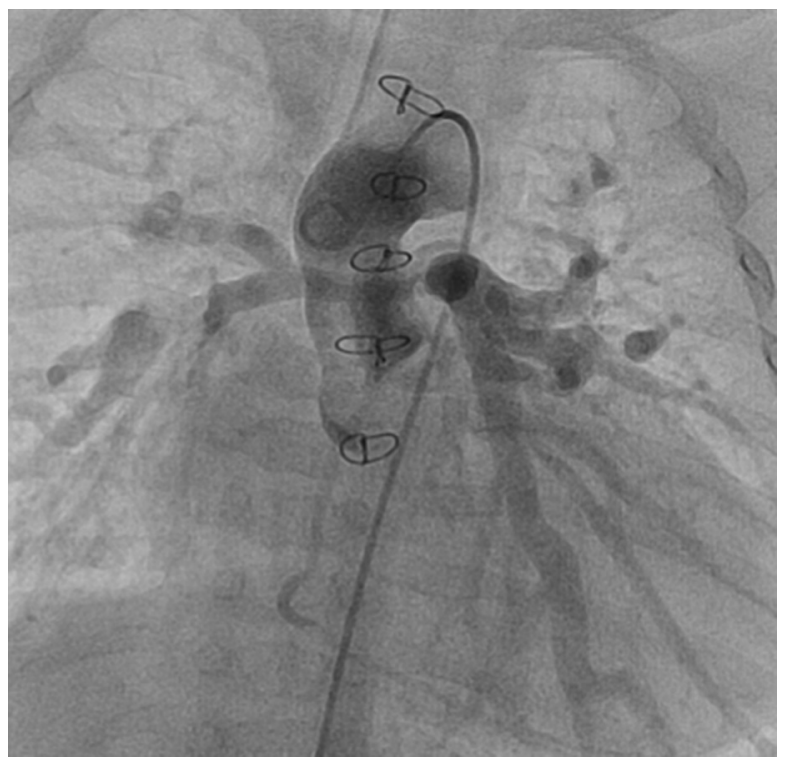

FIGURE 1. Angiogram showing rehabilitated central pulmonary arteries (PA) in a child born with pulmonary atresia, diminutive central PA, and major collaterals supplying bilateral lungs. The child underwent neonatal palliation with implantation of the PA confluence directly into the ascending aorta. 